\title{
A Silver Lining: Women in Reserved Seats in Local Government in Bangladesh
}

\author{
Sohela Nazneen and Sakiba Tasneem
}

\begin{abstract}
The system of reserved seats with direct elections to local government bodies has been in place for women since 1997. This article investigates how perceptions have changed about the role of women representatives in local government. By exploring the accounts of women's views, experiences and how they negotiate various structural and attitudinal obstacles, and the changes in the wider sociopolitical context, the article shows that women representatives have gained greater voice and social legitimacy in representing specific types of 'women's issues.' These gains were partly a result of the supportive policy directives and mechanisms created by the state. Despite these gains, the centralised and andocentric nature of Bangladeshi government and politics may limit the transformatory potential of these changes.
\end{abstract}

\section{Introduction}

In 2003, about 12,684 women were directly elected to the reserved seats in the Union Parishad (UP), the lowest administrative unit of the local government. ${ }^{1}$ Direct election to reserved seats for women in local government - introduced in 1997 (ADB 2004) - replaced the previous system of nomination. This change allowed women a direct link with the electorates and, it was assumed, would increase their legitimacy as representatives. Numerous studies have shown that women elected to these reserved seats face various structural and attitudinal barriers (Hassan 1999; Frankl 2004; Panday 2008). Gender division of labour, restrictions on mobility, lack of knowledge about local government functions, male resistance, gendered nature of local level politics; all have limited women's effective representation and participation. However, this gloomy picture has a silver lining.

In recent years, women representatives have had an increased voice at the community level and have gained social legitimacy in representing certain types of women's issues. Based on an analysis of various existing academic research, and supplemented by interviews with scholars and activists and with female UP members conducted at the Pathways Digital Storytelling workshop held in Dhaka in 2009, ${ }^{2}$ we explore the following questions. What is the qualitative nature of the change in women's voice and legitimacy? What led to these gains? To what extent will these gains made by women transform local politics?

\section{The Bangladesh context}

Bangladesh presents an interesting paradox. Having gained independence in 1971, it is now a democratic, moderate Muslim state with a parliamentary system. But despite the existence of reserved seats and a vibrant feminist movement (Jahan 1995), the political and administrative structure, culture and norms are gender biased (Nazneen and Sultan 2009). The two major political parties are led by women, Sheikh Hasina and Khaleda Zia and, between them, they have held the posts of prime minister and leader of the opposition since 1991. In addition, currently, the home, foreign, agriculture and women's affairs ministries are headed by women. Yet women's rights issues do not have strong currency in Bangladesh politics and, despite women holding these top positions, historically the number of women in different electoral and decision-making bodies has been low. Both Sheikh Hasina and Khaleda Zia came to lead their parties based on their kinship ties.

IDS Bulletin Volume 41 Number 5 September 2010 (c) 2010 The Authors. Journal compilation ( Institute of Development Studies Published by Blackwell Publishing Ltd, 9600 Garsington Road, Oxford OX4 2DQ, UK and 350 Main Street, Malden, MA 02148, USA 
Table 1 Women participating in local government elections

\begin{tabular}{lllll}
\hline Election year & \multicolumn{2}{l}{ Total women candidates } & Women elected to seats \\
\hline & Chair & Member & Chair & Member \\
1997 & 102 & 43,969 (456 contesting in general seats) & 23 & 12,828 (110 elected to general seats) \\
2003 & 232 & 43,764 (617 contesting in general seats) & 22 & 12,684 (79 elected to general seats) \\
\hline
\end{tabular}

Source Based on Khan and Ara (2006).

The provision of reserved seats ensures 30 per cent representation of women in the parliament and various tiers of local government, the Upzilla and Union Parishads. With representation of around 2 per cent, women have not fared well in national parliamentary elections in the general seats (Chowdhury 1994), except for in the most recent one. In the last national election held in 2008, 17 women were directly elected to the general seats. Combined with the 45 women MPs in the reserved seats, the number of women in the current parliament is 65 , the highest since the creation of Bangladesh (Bangladesh Election Commission 2010). However, this numerical gain does not automatically translate into women having a greater voice in decision-making. The women in reserved seats are nominated and not directly linked to an electoral constituency, and some of the 17 women were proxy candidates for husbands or other male relatives unable to contest due to corruption charges. This perception of being proxy candidates limits their power. Given this scenario at the national level, the possible gains in voice and legitimacy made by women Union Parishad members carry significance for women's political empowerment in Bangladesh.

\section{A silver lining: changes in women representatives' voice and legitimacy}

The local government in Bangladesh has three tiers. The Union Parishad (UP), the unit we focus on, at present is the only functional administrative unit at the local level. ${ }^{3}$ The UP is responsible for the economic, social and community development activities of about 10-15 villages and consists of 13 members: a chair, nine general members (can be male or female and are elected by ward) and three women in the reserved seats (elected by zone). ${ }^{4}$ In 1998, the government specified that women representatives should chair at least one-third of the project development committees, would be members of one-third of the project implementation committees and distribute 30 per cent of the resources allocated to the UP by the centre (Hassan 1999). Table 1 shows that significant numbers of women are contesting the reserve and general seats and entering a space deemed as 'male' following the introduction of direct elections in 1997.

Women's entry into these spaces and their experiences in negotiating with other actors have led to changes in their aspirations and increased their voice and legitimacy within their communities. This does not imply the transition into being public representative has been, and is, smooth for women. In fact, it is by negotiating the gender biased culture, attitude and norms that the women representatives acquired skills and knowledge about how to operate in the public sphere and 'how to do politics.'

\subsection{Raising voice and making claims}

For many women UP representatives, the election campaign process of 1997 and 2003 created scope to interact with a large number of people outside their immediate family or community. This is unusual for rural women. Many of these women were not previously politically active (Frankl 2004). Various studies have pointed out that the lack of political apprenticeship and work experience, and purdah norms make women reticent in the UP (Chowdhury 1994; ADB 2004; Panday 2008). However, studies also indicate that campaign and work experience in the UP have led women to learn how to communicate their views, negotiate their positions and to exercise their voice (ADB 2004; Khan and Mohsin 2008). About 78 per cent of 641 women surveyed by Khan and Mohsin (2008) had participated in budget discussions and about 52 per cent had suggested changes during discussions on various proposals. Admittedly, participation in discussions or making suggestions does not automatically imply 
that women representatives have an effective voice. In fact, many women representatives have complained that their views are disregarded by the chair and the male members (Panday 2008). The male resistance experienced by the women is not unique to Bangladesh (Goetz and NyamuMusembi 2008) but the act of women voicing their views at UP meetings and in public in a context where, before direct elections, very few did, is significant.

In fact, women members have become more critical and vocal about the difficulties they experience because of the gender biased attitude and behaviour of male colleagues and the problems that lie within the UP system. One woman put it succinctly, 'This is a system created by the men, for the men, it is not ours' (interview, UP member 1, Pathways Digital Story Workshop, 20 November 2009). Women in both Frankl (2004) and Khan and Mohsin's (2008) study pointed out that they were elected by the people of three wards, whereas their male counterparts were elected by only one, which means they voice the demands of a larger group. Because women in reserved seats are elected by a larger constituency than their male counterparts, this gives them the sense that their voices have legitimacy, and women UP members have expressed this in many forums (The Daily Star, 8 March 2010). One female UP member pointedly said:

Oh, they in the parishad say, '[W]hy does a poor woman have such a loud voice? Who is she?' and I remind them, I was elected directly by people in three wards. I am there to represent their views. I have as much right to speak as they do.

(Interview, UP member 2, Pathways Digital Story Workshop, 20 November 2009)

It perhaps indicates a qualitative shift from the role played by women representatives under the previous nomination system, and also confirms the point raised by Htun (2004) and Alcântara Costa (2010) that how the quota system is implemented affects whether women representatives gain a greater voice. It also demonstrates the impact a direct link to the creation of a personal constituency can have on women's voice (Htun 2004).

Given male resistance, some women have learnt to strategically channel their voice so that it will be heard. This includes using personal networks and creating external and public pressure. One woman told how she ensures that development projects which are stalled by male members are implemented in her constituency:

I use my personal connections and invite the bigwigs in the UP (the chair, the prominent members) to come for a small community gathering or meeting. When they go around and ask people how things are, I ask them for this and that for the people. They cannot say no in front of the people! And I get my development projects.

(Interview, UP member 3, Pathways Digital

Story Workshop, 20 November 2009)

In some cases, women UP members approached other actors to strengthen their voice. They have sought help from the women's organisations for legal, human rights and administrative training to increase their knowledge and skills. They urged the women's organisations to raise these issues in different forums on behalf of women members. In fact, one of the key leaders of Bangladesh Mohila Parishad, the largest women's organisation with 150,000 members, said:

It was after the 1997 elections that the women UP members sought our help to tackle gender bias within UP and ask for training. That is when we realised that our work on women's representation needs to extensively focus on the UP women members... We started pressuring the government. The women ward commissioners in Khulna filed a case in court, demanding they be allowed to exercise their powers as specified in the government circular with our help. And our work on the local government just took off from there...

(Interview, Bangladesh Mohila Parishad 2, 18 July 2008)

This demonstrates the importance of the nature of the link between civil society and the formal political arena for strengthening women's voice (Goetz and Nyamu-Musembi 2008). In some instances, the women decided to directly confront their male colleagues and exercise their voice. Obviously, direct confrontation with a colleague is a costly decision. The decision by these women to do so was brought about by the fact that the offenders had crossed their limit and that these women had external support within the community, or from political leaders and the media. Though these factors enabled 
these few women to take the risk, this cannot be interpreted as a general trend. However, the fact that these women decided to do so in a context where women rarely complain against powerful people in public, carries significance. One female UP member narrated the following incident:

I was harassed by my male colleagues and the UP chairman from the beginning. This was because I was unwilling to participate in the corrupt schemes they had hatched up. At one point, the chairman started a whispering campaign against me alleging that I had loose morals and was going around with men! I had good connections with the local media because of my younger brother. So I decided to go public about the chair's schemes in the local papers ... and this created a feud that reached the district commissioner and party leaders, who intervened and had him apologise to me.

(Interview, UP member 1, Pathways Digital Story Workshop, 20 November 2009)

\subsection{Changing expectations and aspirations of women UP members}

Invariably, women's participation in election campaigns and the investment they made in terms of money, time and effort influenced how women saw their roles as UP members. In Frankl's (2004) study the women interviewed pointed out that since they invested a lot of effort into being elected they did not want to be passive. The following quote highlights what many women UP representatives feel: 'we do not want to be treated like dolls or show pieces, we are not tokens!' (The Independent, 3 February 2010). Studies show that many of them stressed that their role was to: represent the interests of the poor and women, facilitate development work in building infrastructure and ensure that social safety net measures (such as vulnerable group development cards $)^{6}$ were distributed properly (Frankl 2004; Khan and Mohsin 2008; Khan and Ara 2006). Some of them pointed out that people expected them to provide these, and as representatives their legitimacy would be questioned if they failed (Khan and Mohsin 2008). Admittedly, increasing consciousness of their role in local government does not translate into women being effective agents. However, their critique of the system and awareness about development issues (about 65 per cent women in Frankl's (2004) study could elaborate on what the local development issues are) show the women are very clear about their aspirations and roles.
However, not all women UP members are conscious of, or have high aspirations of their role. The ADB (2004) found that about 70 per cent of the women UP members were unclear of their powers and also unaware of the activities of the various UP standing committees. Moreover, some women members expected to use their powers as public officials to benefit their families in order to compensate them for their financial support during election campaigns (Frankl 2004). In addition, proxy representation (male members of the family representing women UP members) is prevalent and many women seek help from their husbands for conducting their affairs as UP members (Khan and Mohsin 2008; Panday 2008; Chowdhury 1994). But some women explained that they sought their husbands' advice since their own experience in dealing with external matters was limited (Khan and Mohsin 2008). They made a clear distinction between asking for advice and deciding a course of action. The women were aware that seeking help from their husbands could be perceived as a weakness by others and they wanted to develop skills to change the situation. One of them stressed that 'one is not given but has to earn their rights, and we are more than willing to learn and fight for them'. In Frankl's (2004) study, many women reported that they had learnt budgetary and project plan and management skills while they served as UP members.

The complaints made by women UP members about the difficulties they face may arise from the fact that they had envisioned a different role for themselves. Panday (2008) shows that in 2003 a lower number of women ran for election compared to 1997, and this may indicate concerns over negative experiences. However, the findings based on the qualitative interviews conducted by other researchers suggest that many women UP members are willing to seek re-election or run in the general seats (Khan and Mohsin 2008). Admittedly, these studies have not extensively reflected on the reasons behind this. However, the changing profile of UP members suggests that these positions have become desirable to women and their families and have perhaps gained legitimacy within the community. Before 1997, it was predominantly housewives who were nominated as UP members. Currently, a significant number of women UP members run small businesses or are other professionals (Khan and Mohsin 2008; Panday 2008; Frankl 
2004). It may be argued that the desirability of these positions is linked to having access to public resources that the family could use for their personal benefit. This perhaps raises questions about whether women representatives would effectively promote women's empowerment related interests (Goetz and Nyamu-Musembi 2008).

\subsection{Gaining social legitimacy}

An area where women UP members have been able to firmly establish their role and legitimacy is in resolving family disputes. The dispute resolution sessions are either held at the UP arbitration council or are administered through an informal committee at the local level (shalish). About 90 per cent of the 641 women UP members interviewed by Khan and Mohsin (2008) had participated in shalish while about 44 per cent reported they had presided over some shalish sessions. Frankl (2004) argued that the provision of reserved seats for women and the government notice that women serve as members of UP committees, created space for women to participate in these shalish.

Undeniably, the space created by these formal provisions was supported by various NGO and women's organisations' training programmes, which focus on alternative dispute resolution and human rights. These programmes targeted women UP members for legal and human rights training. This has changed the nature of the space which used to be male dominated. One female UP member explained,

Women were not a part of the shalish, we could not speak, could not decide but only spoke when we were asked questions. Now, we are preferred by local people, particularly when it comes to women's issues, such as dowry, divorce etc.

(Hassan et al. 2009: 13)

There are several reasons why women were able to gain legitimacy in this area. The community, particularly women, are comfortable in discussing matters related to marriage, divorce, domestic violence, dowry related violence, polygamy, etc. with women UP members. The widely held view within the community and at the official level is that, given their experiences as women, they would be able to understand and empathise with these kinds of problems (Khan and Mohsin 2008). The following story demonstrates this. A female UP member intervened on behalf of an old woman who was being physically abused by her son. The woman approached the female UP member, since she felt that she could only talk about this shameful matter to a woman. Initially, the UP member spoke with the son and asked him to stop. However, after follow-ups she realised that he had not changed his behaviour. The female UP member contacted the local police who responded immediately and arrested the son on domestic violence charges. He was held in jail for 25 days, and after his release his behaviour changed (Frankl 2004).

The male members and chairpersons have not resisted the women's role in these committees. In fact, both of these groups see family disputes as a 'women's issue' (Frankl 2004), where it is 'useful to have a woman since emotions run high and one does need a woman to be there if the issues are about women' (Hassan et al. 2009: 13). Hassan makes the following point about male cooperation:

For male UP members, shalish about family disputes, unless it is about land or involves powerful parties, do not carry the same weight as the various other development projects do. When it comes to VGD or public works projects, women are in direct competition with men regarding patronage distribution, i.e. who gets how many cards, how many people can you provide employment for - since women members represent the same wards as men do. But both male and female members being part of shalish committees do not place them in direct competition with each other.

(Interview, Mirza Hassan, 15 February 2009)

Admittedly, this raises questions about whether it limits women's role and legitimacy to areas that deal with women's concerns. Studies show that women were mainly included in the standing committees that dealt with 'soft issues', i.e. women and children's welfare committees and family planning committees (Hassan 1999; Panday 2008).

Invariably, the current development policy and funding conditionalities in Bangladesh emphasise inclusion and participation of women. This created space for female UP members to be part of the different development initiatives implemented by the government and NGOs. In 
fact, it has become routine practice to include or target female UP members. The reasons being they are elected based on a public mandate and are perceived to have social and political legitimacy at the community level. The female UP members point out that by being a part of these different initiatives, their standing within the community has increased (interview, UP member, Pathways Digital Story Telling Workshop, 20 November 2009). However, whether this form of routinised inclusion builds the capacity of women representatives to effectively represent women's concerns, remains debatable. Despite these questions, the fact that women representatives have gained social legitimacy is important for sustaining the bureaucratic commitment for ensuring women's representation in the formal political sphere (Goetz and Nyamu-Musembi 2008).

\subsection{Transforming local politics?}

The discussion above shows that despite the structural and attitudinal obstacles, women's entry into politics through a system of reserved seats with direct elections, have strengthened their voice and social legitimacy to represent certain types of 'women's issues'. The question is whether this silver lining will lead to larger changes in local politics. The transformatory potential of these changes may be limited by how constituencies are demarcated and the wider political context. As mentioned above, women in reserved seats represent three constituencies, each of which is also represented by a general member, usually male. This creates a strong male resistance. In many instances, women have failed to implement development and public work projects, which has created a perception that more important issues are dealt with by men (Hassan 1999; Frankl 2004; ADB 2004). At times, although women have been part of these committees, they have been used by the chairperson to implement their own projects. In fact, Hassan points out that UP chairs perceive women to be less knowledgeable and more compliant, which is why they prefer to have women in the committees (interview Mirza Hassan, 15 February 2010). Effective participation by women, then, requires different types of skill development and training.

The centralised nature of Bangladesh government and politics remains a key obstacle. The UP is a weak institution since it cannot take any substantive or policy decision without the approval of central government. The central government control on local government pervades all its functions and weakens its financial capacity to act (Khan and Mohsin 2008). This implies that, for women, gains may remain limited to the local level. Being active in a weak institution will not allow women to have a significant impact on political parties or over policy-related decisions.

Many have argued that the political parties and the state were only willing to have direct elections to the reserved seats at the local level and to create other provisions for women's participation, as these were not politically costly. Direct election to reserved seats in parliament has been under consideration since the 1970s, but every single political party has dragged its feet in changing the system. This is because the provision of direct elections in reserved seats would change the current system where women are nominated by party leaders. The number of reserved seats allocated to the majority party and those who are a part of the ruling coalition depends on the proportion of seats won by their members. This, then, allows the ruling party to gain additional seats in the parliament. The reserved seats are also used by the majority party to make deals with their partners in the ruling coalition. In addition, these seats can be distributed as patronage to wives and daughters of those who have been loyal. Thus, the provision of direct elections would be politically costly for the ruling party. Under the current system, the female MPs in the reserved seats do not have a designated constituency until the parliament assigns them one. Those who have won in general seats, usually men, are reluctant for female MPs in reserved seats to contest elections, since they are afraid that this may increase women's voice over what happens in their constituency. The provision that electoral constituencies would rotate as reserved constituencies for women proved even more unpopular among political parties. There was a strong resistance from the men that this would translate into them losing the constituency they had worked so hard to maintain.

However, the recent contestations over devolution of power between the members of parliament and the elected chairpersons and members (including female) of Upzilla and 
Union Parishads show that a scope for collective action by local representatives exists. This may create an opportunity for women representatives to establish strategic links with male members for collective bargaining with the political parties (interview, Mirza Hassan 15 February 2010).

\section{Conclusion}

In summing up, this article shows that it is difficult to draw conclusions about whether quotas or reserved seats lead to effective representation and women's political empowerment through increasing their voice and access to decision-making spaces. In the case of Bangladesh, undeniably, direct elections and inclusion on standing committees has increased the visibility of women. This, in a context where women's empowerment related interests remain unarticulated, has made it viable for women to lay a claim to the formal political sphere (Mansbridge 1999). Moreover, women have gained social legitimacy and acceptance in formally participating and deciding on matters that are perceived as 'women's issues'. All of these indicate that these provisions have partially contributed towards allowing women to put their 'foot in the door'. In other words, these created the opportunity for women to learn the rules of the game and changed their aspirations at the local level. Undeniably, this increase in visibility and creation of social legitimacy is important for ensuring bureaucratic commitment towards political empowerment of women (Mansbridge 1999; Goetz and NyamuMusembi 2008).

However, questions still remain about whether these gains made by women would lead to larger changes at the local level. For transforming local politics, various support systems are required. These include clear demarcation of the roles and responsibilities of female UP members, alliances with women's organisations, effective training programmes run by NGOs and government and strengthening of the UP as an institution through decentralisation. The latter may prove difficult given the centralised structure and nature of political parties and culture in Bangladesh.
So what can we learn from the Bangladesh experience for other contexts? The Bangladesh case confirms that it is not the provisions for reserved seats for women but how these provisions are implemented and the support systems created, that influence the space available to women to transform the political sphere (Alcântara Costa 2010). Whether women elected to reserved seats would 'act for' (Goetz and Hassim 2003) other women remains an open question in Bangladesh as it does in other contexts. Women UP members in Bangladesh have established their legitimacy as actors when it comes to family disputes, but how far they can 'act for' women on economic and infrastructural development issues, where they will face far greater contestation from colleagues, community and state officials, remains to be seen. If women are able to ensure a share of the pie, would and could they act differently in a patron-clientelist system to promote the interests of general women?

These questions perhaps bring us to what Alcântara Costa (2010) points out, that if a few women enter politics, women change, but politics remains the same. If we want politics to change, entry of women into formal politics is a necessary but not sufficient condition. We need to work on changing the patriarchal structure and culture within the political parties and systems. Given the history of military rule and the polarised nature of civil society among two party camps, feminist groups in Bangladesh have been reluctant to engage with political parties, since this undermines their credibility and legitimacy. Although feminist groups have interacted with the female UP members, female MPs and women's wings of political parties; these interactions, while sincere and illuminating, have not led to changes in mainstream politics (Nazneen and Sultan 2009). Perhaps both groups, feminists and women representatives, have to explore alternative ways of engagement and create an understanding that, without women's inclusion and equal participation in all decisionmaking structures, the project of democratisation remains incomplete (Alcântara Costa 2010). 


\section{Notes}

1 The Union Parishad elections were not held in 2008 , but were deferred to after the national elections.

2 Digital story telling as a research and learning method is different from other audiovisual productions since the participant him/herself plans, executes and produces the audiovisual material. This can be an empowering tool for reflection and learning.

3 The Upzilla Parishad elections, the next tier after unions, were held in 2009, but the Upzilla Parishad is yet to be functional.

\section{References}

Asian Development Bank (ADB) (2004) Legal and Institutional Reforms Essential for Inclusive Development, news release, 4 May, Manila: Asian Development Bank

Bangladesh Election Commission (2010) www.ecs.gov.bd (accessed 10 April 2010)

Chowdhury, N. (1994) 'Bangladesh: Gender Issues and Politics in a Patriarchy', in B. Nelson and N. Chowdhury (eds), Women in Politics Worldwide, Yale: Yale University Press

Costa, A.A. (2010) 'Quotas: A Pathway of Political Empowerment?', IDS Bulletin 41.2: 18-27

The Daily Star (2010) 'Achieving Equal Rights', M. Tanjeela, 8 March

Frankl, E. (2004) Quotas and Empowerment: The Use of Reserved Seats in Union Parishad as an Instrument for Women's Political Empowerment in Bangladesh, Working Paper 4, Department of Political Science, University of Stockholm, www.statsvet.su.se/quotas (accessed 2 May 2010)

Goetz, A.M. and Hassim, S. (2003) No Short Cuts to Power: African Women in Politics and Policy Making, London: Zed Books

Goetz, A.M. and Nyamu-Musembi, C. (2008) Voice and Women's Empowerment: Mapping a Research Agenda, Pathways of Women's Empowerment Working Paper 2, Brighton: IDS

Hassan, M. (1999) Local Governance Study: Bangladesh, London: One World Action

Hassan, M.; Nazneen, S. and Rashid, M. (2009) 'Evaluation of Madaripur Legal Aid Association', report prepared for the British
4 Each Union has three zones, within which are three wards.

5 In the South West part of Bangladesh.

6 VGD programmes provide training to vulnerable groups to develop their capacity to enter markets, increase savings and have access to loans. The selected members are also given $30 \mathrm{~kg}$ rice/wheat every month for 18 months. The list of selected people is prepared by the UP members.

High Commission, Dhaka: The British High Commission (unpublished)

Htun, M. (2004) 'Is Gender Like Ethnicity? The Political Representation of Identity Groups', Perspectives on Politics 2.3: 439

The Independent (2010) 'Female Members Can Play Vital Role', 3 February

Jahan, R. (1995) 'Men in Purdah and Women in Public: Rokeya's Dreams and Women's Struggles in Bangladesh', in A. Basu (ed.), The Challenges of Local Feminisms: Women's Movement in Global Perspective, Boulder: Westview Press

Khan, M.R. and Ara, F. (2006) 'Women, Participation and Empowerment in Local Government: The Bangladesh Union Parishad Perspective', Asian Affairs 29.1: 73-92

Khan, Z. R. and Mohsin, A. (2008) 'Women's Empowerment Through Local Governance: Emerging Issues and Debates', paper presented at Pathways of Women's Empowerment RPG Mid Term Review Conference, Cairo, 20-24 January 2009

Mansbridge, K. (1999) 'Should Women Represent Blacks and Blacks Represent Women?: A Contingent Yes', The Journal of Politics 61.3: 628-57

Nazneen, S. and Sultan, M. (2009) 'Reciprocity, Distancing and Opportunistic Overtures: Women's Organisations Negotiating Legitimacy and Space in Bangladesh', IDS Bulletin 41.2: 70-78

Panday, P. K. (2008) 'Representation Without Participation: Quotas for Women in Bangladesh', International Political Science Review 29.4: 489-512 